\title{
Mechanical graphite transport in fault zones and the formation of graphite veins
}

\author{
E. Crespo, J. Luque*, J. F. Barrenechea And M. Rodas
}

Departamento de Cristalografía y Mineralogía, Facultad de Geología, Universidad Complutense de Madrid, 28040 Madrid, Spain

\section{ABSTRACT}

This paper describes a vein-shaped graphite occurrence in which, for the first time, the geological, mineralogical and isotopic evidence support its formation by physical remobilization of previously formed syngenetic graphite. The deposit studied is located in the Spanish Central System and it occurs along the contact between a hydrothermal Ag-bearing quartz vein and a graphite-bearing quartzite layer. The characteristics of this occurrence differ from those of fluid-deposited vein-type graphite mineralization in that: (1) graphite flakes are oriented parallel to the vein walls; (2) graphite crystallinity is slightly lower than in the syngenetic precursor (graphite disseminated in the quartzite); and (3) the isotopic signatures of both types of graphite are identical and correspond to biogenic carbon. In addition, the $P-T$ conditions of the hydrothermal Ag-bearing quartz veins in the study area $\left(P<1 \mathrm{kbar}\right.$, and $T$ up to $360^{\circ} \mathrm{C}$ ) contrast with the high degree of structural order of graphite in the vein. Therefore, physical remobilization of graphite can be regarded as a suitable alternative mechanism to account for some cases of vein-shaped graphite deposits. Such a mechanism would require a previous concentration of disseminated syngenetic graphite promoted, in this case, by the retrograde solubility of quartz. This process would generate monomineralic graphite aggregates enhancing its lubricant properties and permitting graphite to move in the solid state along distances in the range of up to several metres.

KEYWoRDs: graphite deposits, veins, remobilization.

\section{Introduction}

GRAPHITE deposits are grouped into syngenetic (formed through metamorphism of carbonaceous matter), and epigenetic. Epigenetic deposits are also termed 'vein-type', though this term only refers to the morphology of such occurrences since they commonly show vein-like morphology resembling the features of many hydrothermal deposits. Syngenetic graphite in the host rocks compared to the epigenetic deposits shows that the latter has a higher degree of structural ordering and a heavier $\delta^{13} \mathrm{C}$ isotopic signatures (Luque et al., 1998; Kehelpannala 1999; Santosh et al., 2004). Current theories about the origin of vein-type graphite support derivation from the precipitation of solid carbon from C-bearing

*E-mail: jluque@geo.ucm.es

DOI: $10.1180 / 0026461056940266$ fluids (Santosh and Wada 1993; Radhika et al., 1995; Luque et al., 1998; Santosh et al., 2004). Carbon is incorporated into fluids as carbonic species (mainly $\mathrm{CH}_{4}$ and/or $\mathrm{CO}_{2}$ ), either of magmatic or metamorphic provenance, mostly during devolatilization of organic matter and/or through decarbonation reactions. In contrast to fluid derivation, some of the most important veintype graphite deposits (i.e. those of Sri Lanka and India) were formerly interpreted as the result of the physical remobilization of pre-existing disseminated graphite, in the solid state, from the surrounding metasedimentary rocks (Erdosh, 1970; Archaya and Dash, 1984; Acharya and Rao, 1998). However, direct derivation of these graphite veins from syngenetic, metamorphic graphite can be ruled out on the basis of mineralogical and isotopic evidence (e.g. Kehelpannala, 1999; Santosh et al., 2004). 
The present paper describes a case-study of vein-shaped graphite occurrence in which the geological data and the mineralogical and isotopic characterization support its formation by means of the remobilization of graphite in the solid state. The features and mechanism of formation of this occurrence are compared to those of true veintype (fluid-deposited) graphite deposits.

\section{Geological setting}

The Spanish Central System is an ENE-WSW belt located in the internal part of the Iberian Hercynian Belt. The area studied is close to the boundary between the Central and Eastern Complex of the Central System (Capote et al., 1981), west of the Berzosa shear zone (Fig. 1). Different rock units can be distinguished, mainly orthogneisses and a metasedimentary sequence of gneisses, migmatized banded gneisses, finegrained quartzitic gneisses and minor lenses of calc-silicate rocks and dolomitic marble (ITGE, 1991). According to Escuder Viruete et al. (1998), a low- $P$ (<3.5 kbar; ITGE, 1991) high- $T$ metamorphism (early-mid Carboniferous) overprinted earlier Barrovian metamorphic assemblages.
Several deformational phases gave rise to the structural features of the zone. Due to the succession of ductile and brittle events, subvertical folds and high-angle faults developed (Escuder Viruete et al., 1998).

In this area there are several quartz veins with associated Ag-bearing sulphide mineralization, which have been related to late-Hercynian (300-270 Ma) epithermal processes (Doblas et al., 1988; Concha et al., 1992; Tornos et al., 2000). The studied graphite occurrence is located at the contact between one of these Ag-bearing quartz veins and a tightly folded graphite-bearing quartzite (Fig. 1). The country rock is sillimanite gneiss $(\mathrm{Qtz}+\mathrm{Bt}+\mathrm{Sil}$ (fibrolite) $\pm \mathrm{Mu} \pm \mathrm{Pl})$. The interbedded quartzite layer, $0.5-1 \mathrm{~m}$ thick, trends $165^{\circ} / 65^{\circ} \mathrm{E}$. Graphite in the quartzite is mainly concentrated at the base of the layer $(10-20 \%)$ and the flakes are apparently oriented parallel to the original bedding. Towards the top, the layer is strongly fractured with generation of radiated and comb aggregates of quartz. This quartzite layer is crosscut by a $\mathrm{N}-\mathrm{S}$-trending quartz vein dipping $70^{\circ} \mathrm{E}$ which can be followed in a rather continuous outcrop for $\sim 2 \mathrm{~km}$. In the vicinity of the graphite deposit the thickness of the vein is $\sim 2 \mathrm{~m}$, although

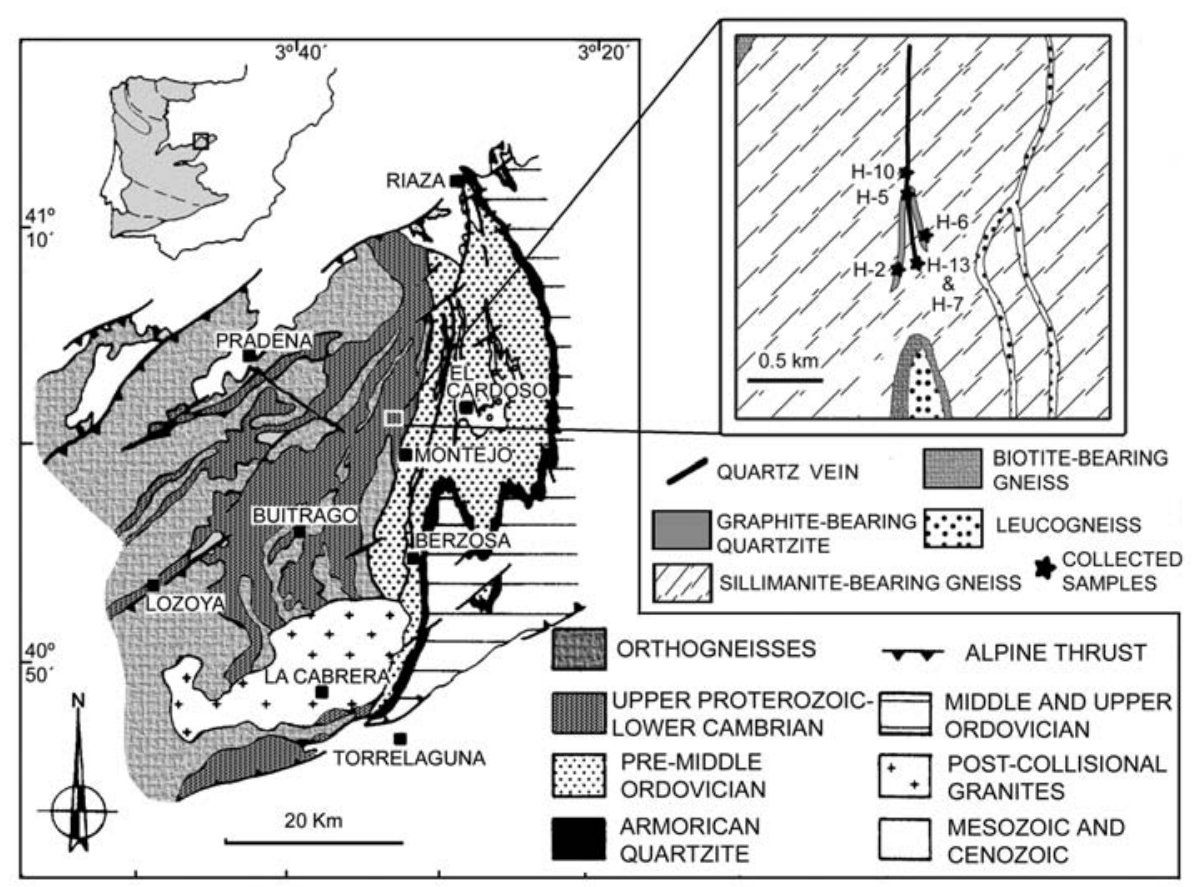

FIG. 1. General geological setting (after Escuder Viruete et al., 1998) and detailed map (modified from ITGE, 1991) of the studied area. 
it may reach up to $10 \mathrm{~m}$. Abundant rounded graphite-bearing quartzite breccia fragments occur within the quartz vein (Fig. 2a). Locally, these fragments give rise to an irregular contact between the quartzite and the quartz vein. No graphite concentrations have been recognized within the brecciated zone, or within the quartz vein. However, graphite concentrations occur as elongated pods and patches, resembling a veinlike morphology (0.5-1 m thick) along the contact between the quartzite and the quartz vein (Fig. $2 b$ ). The graphite crystals parallel the surface of the contact. Centimetre-scale cavities coated with quartz crystals can be observed within the massive graphite concentrations (Fig. 2c).

Therefore, two types of graphite occurrences can be distinguished: graphite disseminated within the quartzite and vein-shaped graphite concentrations along the contact with the quartz vein.

\section{Materials and methods}

The quartzite level was sampled in each flank of the fold out from the quartz vein contact. Samples were also collected from the graphite concentrations along the contact, and following the $\mathrm{S}-\mathrm{N}$ direction of the quartz vein, out of the contact with the graphitic quartzite (Fig. 1). The characterization of the two types of graphite was carried out on concentrates obtained by acid treatment as described by Luque et al. (1993). The structural study of graphite by X-ray diffraction (XRD) was performed with a Siemens Kristalloflex 810 diffractometer, using $\mathrm{Cu}-\mathrm{K} \alpha$ at $30 \mathrm{kV}$ and $40 \mathrm{~mA}$, a step size of $0.03^{\circ} 2 \theta$, and $1 \mathrm{~s}$ per step. Each sample was run at least twice using silicon as internal standard. The Raman spectroscopy study was carried out using a DILOR XY
Raman Spectrometer attached to an Olympus metallographic microscope. The excitation was achieved using an $\mathrm{Ar}^{+}$laser beam focused through the microscope objective. The measurements were made under the usual experimental conditions $(\lambda=514.5 \mathrm{~nm}, 100 \times$ objective, $\mathrm{NA}=0.95)$, so the nominal spatial resolution was $\sim 1 \mu \mathrm{m}$. The position, height, width (FWHM), and area of the disorder peak $\left(D\right.$, at $\left.\sim 1360 \mathrm{~cm}^{-1}\right)$ and order peak $\left(O\right.$, at $\sim 1582 \mathrm{~cm}^{-1}$ ) in the first order Raman spectra were measured. Differential thermal analysis (DTA) curves were obtained by heating the sample at $1^{\circ} \mathrm{C} / \mathrm{min}$ in the range 20 to $1000^{\circ} \mathrm{C}$ with a continuous air supply of $50 \mathrm{ml} / \mathrm{min}$ in a Seiko TG/DTA 320U apparatus. Alumina was used as reference material.

The bulk stable carbon isotope ratio of single grains of graphite from both types of occurrences was measured at the Institute of Geoscience, Shizuoka University (Japan). The equipment and sample preparation were described by SatishKumar et al. (2002) and references therein. Selected samples were also studied at CRPGCNRS (Nancy, France) using a CAMECA ims1270 ion microprobe. Carbon isotope microanalyses of graphite were performed on gold-coated graphite polished sections, sputtered with a $14 \mathrm{keV} \mathrm{Cs}^{+}$primary beam defocused to a $\sim 25-30 \mu \mathrm{m}$ diameter spot. Instrumental mass fractionation was corrected using graphite standards. Secondary ion mass spectrometry (SIMS) analyses presented in this study are considered as single crystal analyses, since the average size of the graphite crystals $(\approx 50 \mu \mathrm{m})$ is similar to the impact area of the laser beam. All the isotopic results are reported in $\delta^{13} \mathrm{C}$ notation relative to the conventional PDB, with a precision of $\pm 0.05 \%$ and $\pm 1 \%$ for bulk and SIMS analysis, respectively.
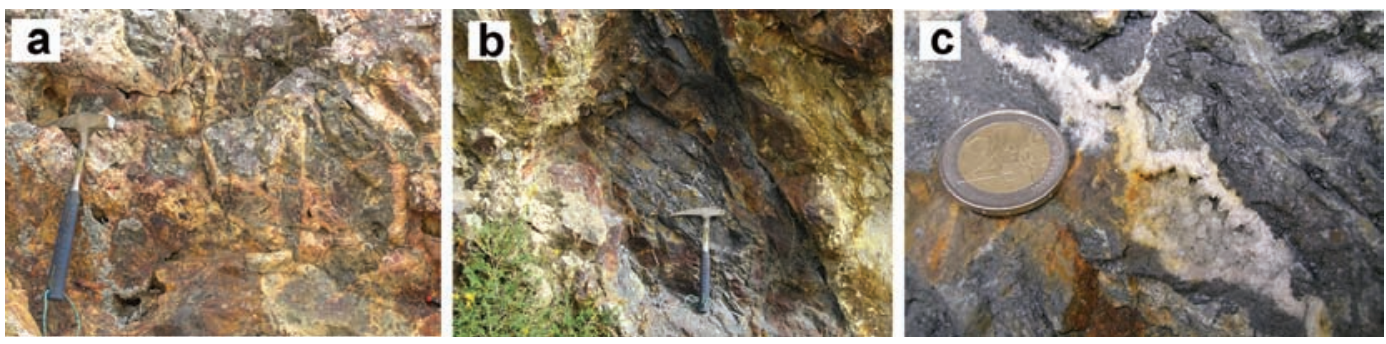

FIG. 2. (a) Field view of brecciated graphite-bearing quartzite fragments included within the quartz vein. (b) Veinshaped graphite along the contact with the quartz vein. (c) Enlarged view of the central part of Fig. $2 b$, showing a cavity coated by a late generation of idiomorphic quartz crystals (coin is $2.5 \mathrm{~cm}$ wide). 


\section{Results}

Graphite in the quartzite occurs as disseminated flakes with sizes of $\sim 100 \mu \mathrm{m}$ displayed along the boundaries of quartz grains. Vein-like concentrations consist of an accumulation of irregularly shaped smaller graphite crystals $(25$ to $60 \mu \mathrm{m})$. Graphite in all the samples has a high degree of structural order, as revealed by the XRD data (Table 1). However, the $c$ parameter is slightly lower in the graphite disseminated in the quartzite $(c=6.708-6.709 \AA)$ than in the samples from the vein-shaped occurrence $(c=6.712-6.720 \AA)$. Temperature estimations using the $c$ parameter of graphite (Shengelia et al., 1979) range from 600 to $720^{\circ} \mathrm{C}$, the lowest values corresponding to graphite within the vein. Crystallite size $\left(L_{\mathrm{c}}\right)$ of graphite disseminated within the quartzite range from 446 to $530 \AA$ and are consistently lower in the mineralized vein, where $L_{\mathrm{c}}$ values average $385 \AA$. Conversely, $L_{\mathrm{a}}$ values of graphite are similar both in the quartzite and in the vein. The DTA results show that all the studied samples display similar starting and final temperatures of combustion. The value for exothermic maximum temperatures ranges from 673 to $772^{\circ} \mathrm{C}$.

Stable carbon isotope analyses reveal that all the samples show light $\delta^{13} \mathrm{C}$ signatures $(<-25 \%)$ and a similar range of values (Fig. 3). The widest range corresponds to graphite within the vein $\left(\delta^{13} \mathrm{C}=-26\right.$ to $\left.-33 \%\right)$, whereas the range for graphite disseminated in the quartzite is slightly narrower $\left(\delta^{13} \mathrm{C}=-26\right.$ to $\left.-31 \%\right)$.

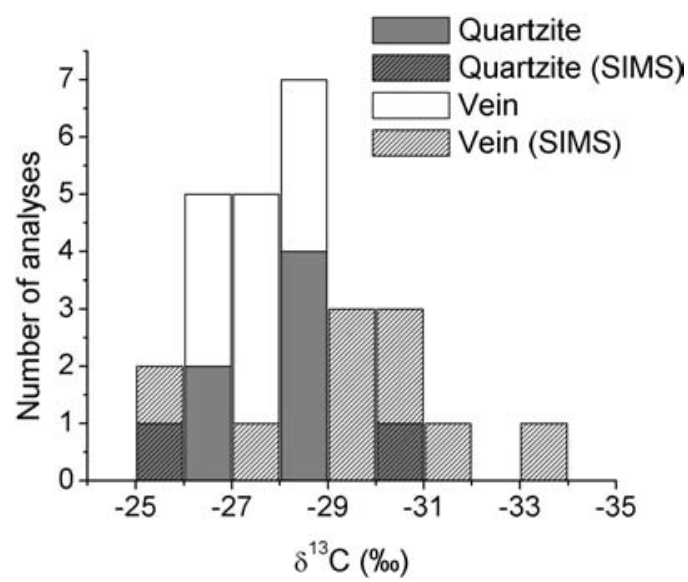

FIG. 3. $\delta^{13} \mathrm{C}$ values (bulk and SIMS analyses) for the two types of graphite samples.

\section{Discussion}

The mode of occurrence of graphite within the quartzite as disseminated flakes in the studied occurrence along with its light, clearly biogenic isotopic signature $\left(\delta^{13} \mathrm{C}<-25 \%\right.$ ) indicates that graphite formed through the metamorphic evolution of the organic matter dispersed in the sediments. The $d_{002}$ values $(3.354-3.355 \AA)$ and crystallite size $\left(L_{\mathrm{c}}=466-530 \AA\right.$; $L_{\mathrm{a}}$ in excess of $2000 \AA$ ) are within the range estimated for medium- to high-grade metamorphic rocks (Kwiecinska, 1980; Wopenka and Pasteris, 1993) and these data agree with the metamorphic grade of the host rock to the graphite. In addition, the temperatures obtained from the $c$ parameter of graphite using the geothermometric estimation of Shengelia et al. (1979) range from 708 to $720^{\circ} \mathrm{C}$ which agrees with the metamorphic facies of the host rocks. Finally, the values of the exothermic peak for the graphite disseminated within the quartzite $\left(T_{\max }=700-770^{\circ} \mathrm{C}\right)$ are also within the range given for graphite in sillimanite-facies rocks (Kwiecinska, 1980). All these data suggest therefore that graphite in the quartzite is syngenetic and that its degree of structural ordering was achieved through the sillimanitefacies metamorphism that affected the area studied.

Graphite concentrated along the contact with the quartz vein, however, requires a different mechanism to explain its occurrence. Fluid inclusion studies (Martín-Crespo et al., 2002) have shown that fluids that generated the Agbearing quartz veins were mainly aqueous $\left(\mathrm{H}_{2} \mathrm{O}\right.$ $>93 \%$ ) with salinities of $0.5-7 \% \mathrm{NaCl}$ equivalents. Temperatures of homogenization of these fluid inclusions are up to $360^{\circ} \mathrm{C}$ and pressure is estimated to be $<1 \mathrm{kbar}$. Such temperatures do not match the temperature estimated from the $c$ parameter of graphite $\left(600-675^{\circ} \mathrm{C}\right)$. The mineralogical characteristics of graphite in the studied vein-shaped occurrence are very similar to those of graphite disseminated within the quartzite. Stable carbon isotopic signatures of both types of graphite correspond to biogenic carbon.

Remobilization as a suitable mechanism for the formation of ore deposits has been invoked by different authors (Hobbs, 1987; Boyle, 1991). In particular, Hobbs (1987) proposed that solid state remobilization could operate at the local scale for the concentration of low-hardness minerals such as galena at the Broken Hill and Mt. Isa deposits in Australia. Graphite is also a low-hardness 
MECHANICAL GRAPHITE TRANSPORT

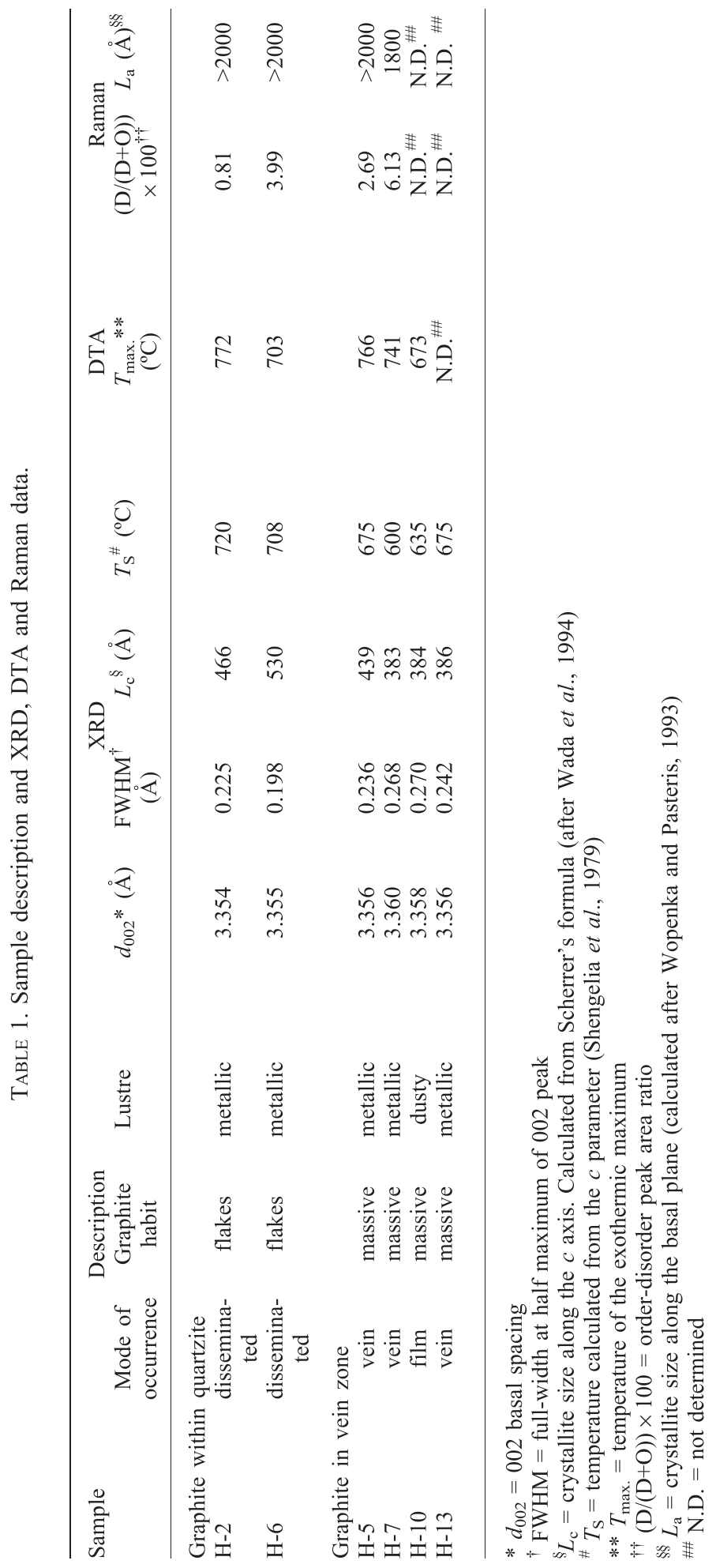


mineral and remobilization through pressure gradients has been considered as the concentration mechanism for some world-class vein-type deposits (e.g. Sri Lanka and India; Erdosh, 1970; Acharya and Dash, 1984; Acharya and Rao, 1998). However, the long transport distance between the epigenetic and syngenetic occurrences, the higher crystallinity of epigenetic graphite compared to the syngenetic one, and their different isotopic signature, have been argued as evidence against this mechanism (Katz, 1987; Silva, 1987; Dissanayake, 1994; Kehelpannala, 1999; Santosh et al., 2004).

In the vein-shaped graphite occurrence studied the temperatures estimated from the $c$ parameter are below those reported for the formation of coarse graphite flakes through reduction from $\mathrm{CO}_{2}$-rich fluids under granulite-facies conditions in most of the fluid-deposited vein-type deposits (see for example, Lamb and Valley, 1984; Santosh and Wada, 1993; Santosh et al., 2004). In addition, many of the objections to the remobilization mechanism can be overcome, bearing in mind the following: (1) the temperature and pressure operating during graphite concentration were those of hydrothermal environments ( $T<360^{\circ} \mathrm{C}, P \sim 1000$ bar); (2) the remobilization process was favoured by a drop in pressure (as revealed by the hydraulic fracturing caused by the fluids that generated the quartz vein); and (3) the presence of an aqueous fluid could provide water vapour that would form films coating the surface of graphite grains lowering their friction coefficient (Ubbelohde and Lewis, 1960). Under these conditions, graphite could be mobilized in the solid state. However, the source of graphite for the vein-shaped occurrence is disseminated through a mechanically hard rock (quartzite), in which mobilization of graphite along quartz-grain boundaries would be difficult. This difficulty could be overcome by partial dissolution of quartz in the graphite-bearing quartzite, as documented by Kadounová (1992). Simultaneous quartz dissolution in the source rock and hydrothermal quartz precipitation in the vein may be explained by retrograde solubility, which would lead to quartz dissolution over a short temperature range (Fournier, 1985; Von Damm et al., 1991). The $P-T$ range in which such a process could take place (Von Damm et al., 1991) is close to that estimated from fluid inclusion data in the Ag-bearing quartz veins of this study. Moreover, the higher graphite content at the base of the quartzite level and the rounded appearance of quartzite fragments within the 'brecciated' zone also support the dissolution process.

The vein-shaped graphite occurrence described in this paper can therefore be explained by the mechanical transport of monomineralic aggregates resulting from the partial dissolution of the quartz grains of the graphite-bearing quartzite. Although this mechanism took place in a fluidmediated environment, the isotopic characteristics of the mobilized graphite remained unaffected due to the absence of carbonic species within the fluids (Martín-Crespo et al., 2002), and the sluggish kinetics of carbon diffusion once graphite is fully crystallized (Scheele and Hoefs, 1992). The local stress field caused the movement of graphite towards low-pressure zones. The mechanical disruption of graphite in the quartzite during this process led to the diminution of the particle size of graphite crystals within the vein. As movement occurred mainly along the basal plane (the active slip directions), the continuity of graphite crystals along the stacking direction was also disrupted resulting in lower $L_{\mathrm{c}}$ values (Table 1). This conclusion is supported by experimental evidence which shows that once graphite attains a certain degree of structural ordering, shear stress involves a decrease in the "crystallinity" parameters (Salver-Disma et al., 1999; Wakayama et al., 1999; Ong and Yang, 2000). There are no significant differences in the $L_{\mathrm{a}}$ values between graphite disseminated in the quartzite and graphite in the vein. This is consistent with the proposed mechanism of remobilization of graphite by movement along the basal plane. Such a mechanism also appears to be responsible for the different orientation of graphite crystals (parallel to the contact of the vein) with respect to that found in veins formed by precipitation from carbon-bearing fluids (perpendicular to the vein walls). Compared to deposition from fluids, the physical mobilization of graphite as a mineralization process appears to operate over shorter distances. Based on the geometric relationships between quartzite-hosted graphite and graphite-vein the transport distances can be estimated to be from a few centimetres to some metres. It must be taken into account, however, that graphite deposits formed by metamorphism are by far the most abundant type and that physical remobilization can be regarded as an efficient mechanism to concentrate a disseminated ore within a much smaller volume of rock. Future new findings of this type of 
graphite deposit will allow us to constrain the economic interest of the physical remobilization mechanism.

\section{Acknowledgements}

Thanks are due to Professor J.M. Montesinos for helping with the field location of the occurrence. Dr R. Rojas is gratefully acknowledged for assistance during the thermal studies. Dr C. Prieto helped during the Raman analyses. Professor C. Casquet and Dr L. Ortega are also thanked for helpful comments. The paper was improved through the comments of an anonymous referee. This paper is a contribution from project PB98-0836 of the Spanish CICYT.

\section{References}

Acharya, B.C. and Dash, B. (1984) Graphite in Eastern Ghats Precambriam migmatites, Orissa, India. Transactions Royal Society of Edinburgh, Earth Science, 75, 391-406.

Acharya, B.C. and Rao, D.S. (1998) Graphite in Eastern Ghat Complex of Orissa. Geological Survey of India, Special Publication, 44, 190-200.

Boyle, R.W. (1991) Auriferous Archean greenstonesedimentary belts. Economic Geology, Monograph 8, 164-191.

Capote, R., Casquet, C. and Fernández-Casals, M.J. (1981) La tectónica hercínica de cabalgamientos en el Sistema Central Español. Cuadernos Geología Ibérica, 7, 455-469.

Concha, A., Oyarzun, R., Lunar, R., Sierra, J., Doblas, M. and Lillo, J. (1992) The Hiendelaencina epithermal silver-base metal district, Central Spain: tectonic and mineralizing processes. Mineralium Deposita, 27, 83-89.

Dissanayake, C.B. (1994) Origin of vein graphite in high-grade metamorphic terrains. Mineralium Deposita, 29, 57-67.

Doblas, M., Oyarzun, R., Lunar, R., Mayor Yagüe, N. and Martínez Frías, J. (1988) Detachment faulting and late Paleozoic epithermal Ag-base-metal mineralization in the Spanish Central System. Geology, 16, 800-803.

Erdosh, G. (1970) Geology of Bogala Mine, Ceylon and the origin of vein-type graphite. Contributions to Mineralogy and Petrology, 5, 375-382.

Escuder Viruete, J., Hernáiz Huerta, P.P., ValverdeVaquero, P., Rodriguez Fernández, R. and Dunning, G. (1998) Variscan syncollisional extension in the Iberian Massif: structural, metamorphic and geochronological evidence from the Somosierra sector of the Sierra de Guadarrama (Central Iberian Zone,
Spain). Tectonophysics, 290, 87-109.

Fournier, R.O. (1985) The behaviour of silica in hydrothermal systems. Reviews in Economic Geology, 2, 45-61.

Hobbs, B.E. (1987) Principles involved in mobilization and remobilization. Ore Geology Reviews, 3, 37-45.

ITGE (1991) Mapa Geológico de España, serie 2, $1^{a}$ edición. Instituto Geológico de España, Hoja $\mathrm{n}^{\circ} 458$ (Prádena), scale 1:50.000, 1 sheet.

Kadounová, Z. (1992) Behaviour of graphite during regional metamorphism and deformation of sedimentary rocks of the Bohemian Massif, Czechoslovakia. Casopis pro Mineralogii a Geologii, 37, 135-143.

Katz, M.B. (1987) Graphite deposits of Sri Lanka: a consequence of granulite facies metamorphism. Mineralium Deposita, 22, 18-25.

Kehelpannala, K.V.W. (1999) Epigenetic vein graphite mineralization in the granulite terrain of Sri Lanka. Gondwana Research, 2, 654-657.

Kwiecinska, B. (1980) Mineralogy of natural graphites. Polska Akademia Nauk, Prace Mineralogiczne, 67, 5-79.

Lamb, W. and Valley, J.W. (1984) Metamorphism of reduced granulites in low- $\mathrm{CO}_{2}$ vapour-free enviroment. Nature, 312, 56-58.

Luque, F.J., Barrenechea, J.F. and Rodas, M. (1993) Graphite geothermometry in low and high temperature regimes: two case studies. Geological Magazine, 130, 501-511.

Luque, F.J., Pasteris, J.D., Wopenka, B., Rodas, M. and Barrenechea, J.F. (1998) Natural fluid-deposited graphite: mineralogical characteristics and mechanisms of formation. American Journal of Science, 298, 471-498.

Martín-Crespo, T., Vindel, E. and López-García, J.A. (2002) La mineralización de As-Ag de Bustarviejo: un ejemplo de la actividad hidrotermal pérmica en el Sistema Central. Boletín Sociedad Española Mineralogía, 25A, 53-54.

Ong, T.S. and Yang, H. (2000) Effect of atmosphere on the mechanical milling of natural graphite. Carbon, 38, 2077-2085.

Radhika, U.P., Santosh, M. and Wada, H. (1995) Graphite occurrences in southern Kerala: characteristics and genesis. Journal of the Geological Society of India, 45, 653-666.

Salver-Disma, F., Du Pasquier, A., Tarascon, J.M., Lassègues, J.C. and Rouzaud, J.N. (1999) Physical characterization of carbonaceous materials prepared by mechanical grinding. Journal of Power Sources, 81-82, 291-295.

Santosh, M. and Wada, H. (1993) Microscale isotopic zonation in graphite crystals: evidence for chaneled $\mathrm{CO}_{2}$ influx in granulites. Earth and Planetary Science Letters, 119, 19-26. 


\section{E. CRESPO ET AL.}

Santosh, M., Wada, H., Satish-Kumar, M. and Binu-Lal, S.S. (2004) Carbon isotope "stratigraphy" in a single graphite crystal: Implications for the crystal growth mechanism of fluid-deposited graphite. American Mineralogist, 88, 1689-1696.

Satish-Kumar, M., Wada, H. and Santosh, M. (2002) Constraints on the application of carbon isotope thermometry in high- to ultrahigh-temperature metamorphic terranes. Journal of Metamorphic Geology, 20, 335-350.

Scheele, N. and Hoefs, J. (1992) Carbon isotope fractionation between calcite, graphite and $\mathrm{CO}_{2}$ : an experimental study. Contributions to Mineralogy and Petrology, 112, 35-45.

Shengelia, D.M., Akhvlediani, R.A. and Ketskhoveli, D.N. (1979) The graphite geothermometer. Dokladii Akademic Nauk SSSR, 235, 132-134.

Silva, K.K.M.W. (1987) Mineralization and wall-rock alteration at the Bogala graphite deposit, Bulathkohupitiya, Sri Lanka. Economic Geology, 82, 1710-1722.

Tornos, F., Delgado, A., Casquet, C. and Galindo, C. (2000) 300 Million years of episodic hydrothermal activity: stable isotope evidence from hydrothermal rocks of the Eastern Iberian Central System. Mineralium Deposita, 35, 551-569.
Ubbelohde, A.R. and Lewis, F.A. (1960) Graphite and its Crystal Compounds. Clarendon Press, Oxford, $\mathrm{UK}, 217 \mathrm{pp}$.

Von Damm, K.L., Bischoff, J.L. and Rosenbauer, R.J. (1991) Quartz solubility in hydrothermal seawater: an experimental study and equation describing quartz solubility for up to $0.5 \mathrm{M} \mathrm{NaCl}$ solutions. American Journal of Science, 291, 977-1007.

Wada, H., Tomita, T., Matsuura, K., Iuchi, K., Ito, M. and Morikiyo, T. (1994) Graphitization of carbonaceous matter during metamorphism with references to carbonate and pelitic rocks of contact and regional metamorphisms, Japan. Contributions to Mineralogy and Petrology, 118, 217-228.

Wakayama, H., Mizuno, J., Fukushima, Y., Nagano, K., Fukunaga, T. and Mizutani, U. (1999) Structural defects in mechanically ground graphite. Carbon, 37, 947-952.

Wopenka, B. and Pasteris, J.D. (1993) Structural characterization of kerogens to granulite-facies graphite: applicability of Raman micrprobe spectroscopy. American Mineralogist, 76, 533-557.

[Manuscript received 11 January 2005:

revised 12 April 2005] 